\title{
Cordyceps locustiphila (Hypocreales: Cordycipitaceae) infecting the grasshopper pest Tropidacris collaris (Orthoptera: Acridoidea: Romaleidae)
}

\author{
Sebastian A. Pelizza ${ }^{1,2^{*}}$, María C.Scattolini ${ }^{1}$, Cristian Bardi ${ }^{1}$, Carlos \\ E. Lange ${ }^{1,4}$, Sebastian A. Stenglein ${ }^{3}$ and Marta N. Cabello ${ }^{2,4}$
}

${ }^{1}$ Centro de Estudios Parasitológicos y de Vectores (CEPAVE), CCT La Plata-CONICETUNLP, Boulevard 120 s/n entre Av. 60 y Calle 64, La Plata (1900), Argentina

2 Instituto de Botánica Carlos Spegazzini (FCNyM-UNLP), Calle 53 \# 477, La Plata (1900), Argentina

${ }^{3}$ Laboratorio de Biología Funcional y Biotecnología (BIOLAB)-CICBA-INBIOTEC, Facultad de Agronomía de Azul, UNCPBA, Republica de Italia \# 780, Azul (7300), Argentina

${ }^{4}$ Comisión de Investigaciones Científicas de la Provincia de Buenos Aires (CICPBA)

With 3 figures

\begin{abstract}
Cordyceps locustiphila is described, illustrated, and compared with a previous finding. This species was collected infecting Tropidacris collaris in the Yabotí biosphere reserve, Misiones province, Argentina. Until now, this entomopathogenic fungus has not been reported affecting T. collaris, and it is the first report for Argentina. From the cordyceps-like stromata of $C$. locustiphila it was possible to isolate for the first time the acremonium-like anamorph of this fungus. The identity of both, anamorph and teleomorph, was determined by morphological and molecular taxonomic studies, which challenges the recent new combination into Beauveria.
\end{abstract}

Key words: entomogenous fungi, insect pathogens, tropical biodiversity.

\section{Introduction}

Fungi with cordyceps-like teleomorph are most diverse in the family Cordycipitaceae in terms of both number of known species and host range (Kobayasi 1941, Sung et al. 2007a). There are estimated to be more than 400 species names under Cordyceps (Mains 1958, Stensrud et al. 2005) although this is expected to be an underestimation of the

\footnotetext{
*Corresponding author: pelizza@ cepave.edu.ar 
extant global diversity (Hawksworth \& Rossman 1997). A phylogenetic classification based on molecular data separated the species across three families, Cordycipitaceae, Clavicipitaceae and Ophiocordycipitaceae (Sung et al. 2007b, Sanjuan et al. 2014). Cordyceps-like fungi have the highest species diversity in subtropical and tropical regions (Samson et al. 1988) such as tropical areas of Brazil (Andrade 1980, Evans \& Samson 1982, Evans et al. 2011), Colombia (Kobayasi 1981, Sanjuan et al. 2001, 2014, 2015) Ecuador (Kobayasi 1981, Evans \& Samson 1982), and Bolivia (Mains 1959). In Argentina, these fungi had been found infecting different insects (Spegazzini 1919, Marchionatto 1945, Mains 1954, 1959, Yasem de Romero 1984, López Lastra 1989, Mueller \& Rajchenberg 1991). Cordyceps locustiphila was described by Hennings (1904) as a species with gregarious or solitary, claviform, yellow stromata. The original illustration shows the fungus emerging from the abdomen and the coxa of an adult locust (Orthoptera: Acrididae). For molecular phylogenetic and nomenclatural reasons, this species was transferred to Beauveria (Kepler et al. 2017).

The romaleid Tropidacris collaris (Stoll) (Orthoptera: Acridoidea: Romaleidae), one of the largest grasshoppers known $(\hat{\sigma}=73-101 \mathrm{~mm}, q=92-126 \mathrm{~mm})$, has become in recent years a recurrent and extended pest in areas of some of the northern provinces of Argentina (Catamarca, Chaco, Córdoba, La Rioja, Santiago del Estero), particularly in olive and jojoba plantations (Cigliano et al. 2014).

Until now, except for an undescribed Gregarina sp. (Bardi et al. 2009), pathogens have not been reported affecting T. collaris. Here we first report for Argentina by morphological and molecular studies an isolate of C. locustiphila from T. collaris. Moreover, from stromata of $C$. locustiphila we were able to isolate for the first time the asexual phase of this fungus, whose characters, were studied with morphological observations and molecular techniques.

\section{Materials and methods}

Field COLLeCtion: The specimen of T. collaris that was infected by C. locustiphila was found in the Yabotí biosphere reserve $\left(26^{\circ} 37^{\prime} \mathrm{S}, 53^{\circ} 40^{\prime} \mathrm{W}\right)$, a natural protected area that covers parts of the departments of Guaraní and San Pedro in Misiones province, Argentina. The area presents an extension of 235,959 ha and belongs to the Selva Paranaense (Parana forest) eco-region (Cabrera \& Willink 1973, Morrone 2014). The climate is subtropical without dry season (Cabrera \& Willink 1973, Di Bitetti et al. 2003). Average temperatures range from $24^{\circ} \mathrm{C}$ in summer to $14^{\circ} \mathrm{C}$ in winter. The rainfall is $1800 \mathrm{~mm}$ annually, concentrated in the summer season. This reserve has an exuberant jungle, made up of lianas, epiphytic plants, ferns, and tree species such as black laurel [Nectandra saligna Nees \& Mart.], white guatambú [Balfourodendron riedelianum (Engl.) Engl.], yerba mate (Ilex paraguariensis A. St.-Hil.), and guayubira (Patagonula americana L.), among many others. The grasshopper T. collaris was collected in January 2015 in a region within the reserve that was not altered by human activity, where there are recorded temperatures of $24^{\circ} \mathrm{C}$ and an ambient humidity of $90 \%$. The grasshopper T. collaris infected with C. locustiphila was placed in a plastic box with silica gel and deposited at the Herbarium of the Spegazzini Institute of Botany of La Plata National University, with access code LPS 49245.

MoRPHOLOGICAL OBSERVATIONS: In the laboratory, fungal stromata were taken from the infected insect. They were surface-sterilized by dipping them successively in $70 \%$ ethanol (10-15 s), $0.5 \%$ sodium hypochlorite solution (1 min), and sterile distilled water (1 min, two consecutive baths) according to Lacey \& Solter (2012). Stromata were allowed to dry at room temperature under a laminar flow 

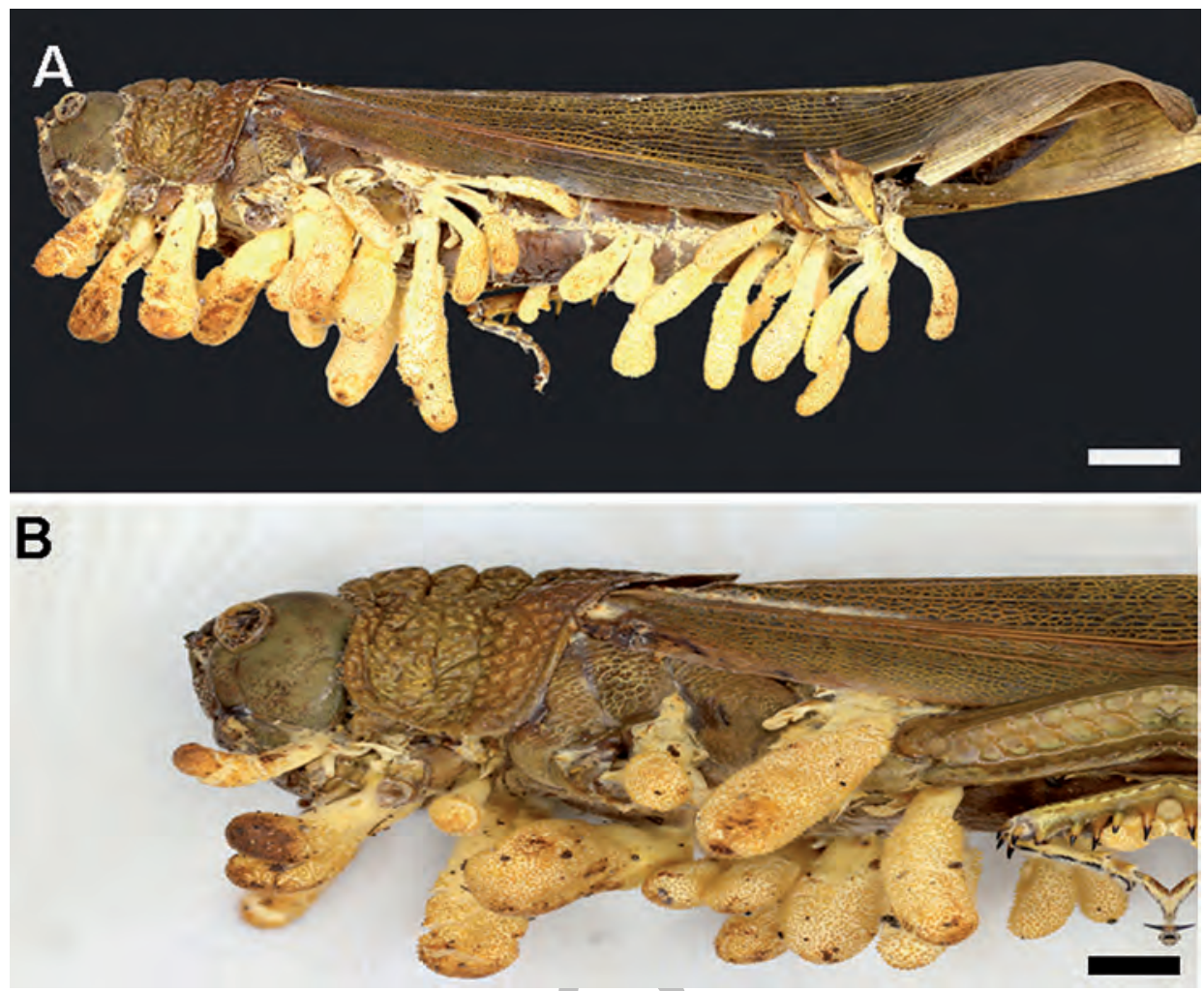

Fig. 1. Stromata of Cordyceps locustiphila growing on Tropidacris collaris grasshopper. Bars: A = $6 \mathrm{~mm} ; \mathrm{B}=4 \mathrm{~mm}$.

chamber. Then each stroma was cut longitudinally into two equal halves with a sterile scalpel, and deposited on a Petri dish containing potato dextrose agar (PDA) plus antibiotics $(0.1 \%$ stock antibiotics consisting of $0.02 \mathrm{~g}$ each of tetracycline, streptomycin and penicillin) as culture medium. The plates were then incubated at $25^{\circ} \mathrm{C}$ for 7 days, after which fungal isolates were transferred to fresh PDA. A culture was deposited in the living strain collection of LPS under the number LPSc \#1218. Some stromata were fixed with a Bouin's solution and prepared (Becnel 2012) to perform histological sections for observation of stipes, perithecia, ascospores, and asci under stereoscopic and optical microscopes with phase contrast to corroborate the taxonomic identification using available keys and databases (Kobayasi 1941, 1981, Luangsa-ard et al. 2008).

DNA EXTRACTION, PCR, AND SEQUENCING: To confirm the morphological identification, a portion of the stroma and cultivated mycelium were placed separately in CTAB buffer to perform the extraction of total DNA following the procedure described by Stenglein \& Balatti (2006), then amplifications were performed by the Polymerase Chain Reaction (PCR). The regions corresponding to the internal transcriber spacer region (ITS) and to the elongation factor $1 \alpha$ gene (TEF) were amplified according to Sanjuan et al. (2014), using primers ITS4 / ITS 5 (White et al. 1990) and 983F / 2218R (Rehner \& Buckley 2005), respectively. Finally, the samples obtained were sequenced and deposited at GenBank (accession numbers: MF185185; MF185186; MF185187; MF185188). The sequences were submitted to BLAST searches at GenBank. 

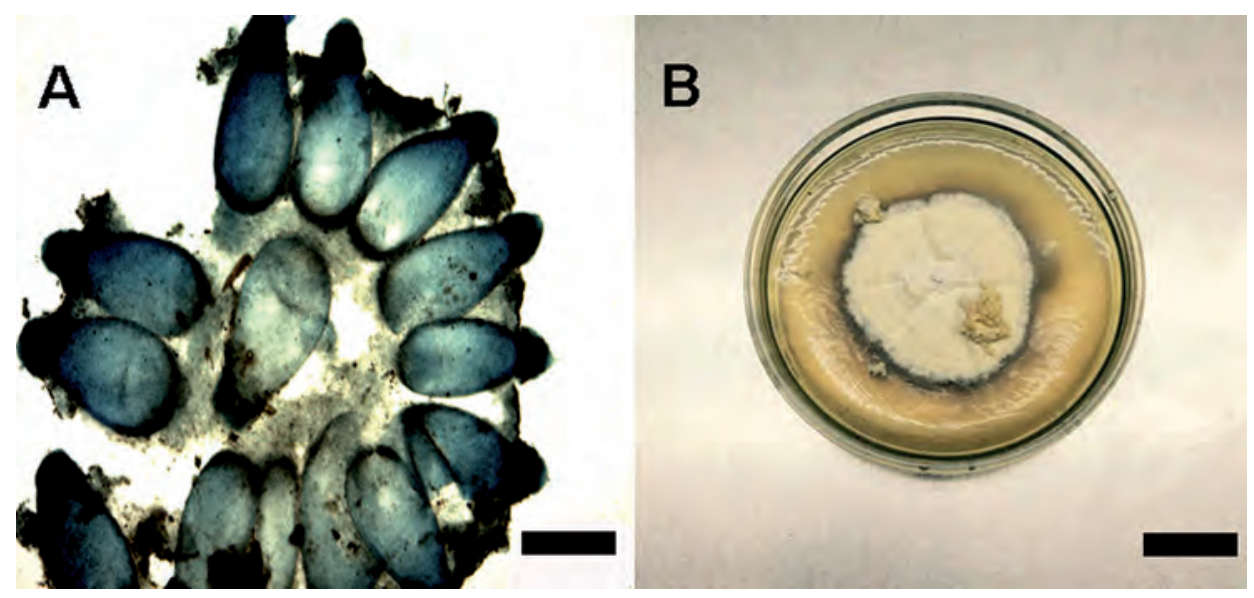

Fig. 2. A: Perithecia (in cotton blue) of Cordyceps locustiphila. B: Colony on PDA after 15 days at $25^{\circ} \mathrm{C}$. Bars: $\mathrm{A}=150 \mu \mathrm{m} ; \mathrm{B}=15 \mathrm{~mm}$.

\section{Results}

\section{Taxonomic description}

Cordyceps locustiphila Henn., Fungi amazonici II. a cl. Ernesto Ule collecti. Hedwigia 43: 246 (1904).

Teleomorph characteristics (LPS\#49245): Stromata gregarious, claviform, simple, bright yellow (Fig. 1A-B), 5-10 mm long. Fertile head clavate, slightly echinulate by protruding perithecial ostioles, bright yellow, 3-5 $\times 2-4 \mathrm{~mm}$ long. Stipe fleshy, terete, sometimes caespitose, grayish yellow, 1-4 × 1-2 mm. Perithecia semi-immersed, with perpendicular orientation, ovoid, 358-488 $\times 138-232 \mu \mathrm{m}(\mathrm{n}=20)$, wall less than $50 \mu \mathrm{m}$ wide (Fig. 2A). We did not observe the presence of asci and ascospores, because stromata of $C$. locustiphila did not mature, even after placing them in humid chamber. ITS (accession number: MF185185) and TEF (accession number: MF185186) sequences obtained from the culture mycelium showed $100 \%$ similarity with GenBank accessions JQ958609 and JQ958619 of C. locustiphila, respectively.

\section{Anamorph characteristic}

Colonies obtained from stroma tissue slow-growing, after 15 days on PDA at $25^{\circ} \mathrm{C} 30$ $\mathrm{mm}$ diam., ocher yellow, white near margin; reverse pale yellow (Fig. 2B). Hyphae 1.5-2.5 $( \pm 0.08)(\mathrm{n}=50) \mu \mathrm{m}$ wide. Phialides acremonium-like, simple, awl-shaped, erect, sessile phialides from the substrate 40.6-56.8 $( \pm 5.38) \times 1.1-2.1( \pm 0.34) \mu \mathrm{m}$ $(\mathrm{n}=50)$ wide at the base and 0.71-1.25 $( \pm 0.18) \mu \mathrm{m}$ wide at the tip $(\mathrm{n}=50)$ (Fig. 3). Conidia hyaline, smooth, cylindrical, slightly clavate or allantoid, 1.2-3.1 $( \pm 0.63)$ $\times 4.7-9.8( \pm 1.79) \mu \mathrm{m}(\mathrm{n}=100)$, always arranged in slime drops or solitary (Fig. 3). Sequences of the anamorph in culture differed only at bp position $391(\mathrm{C} / \mathrm{G})$ for the 


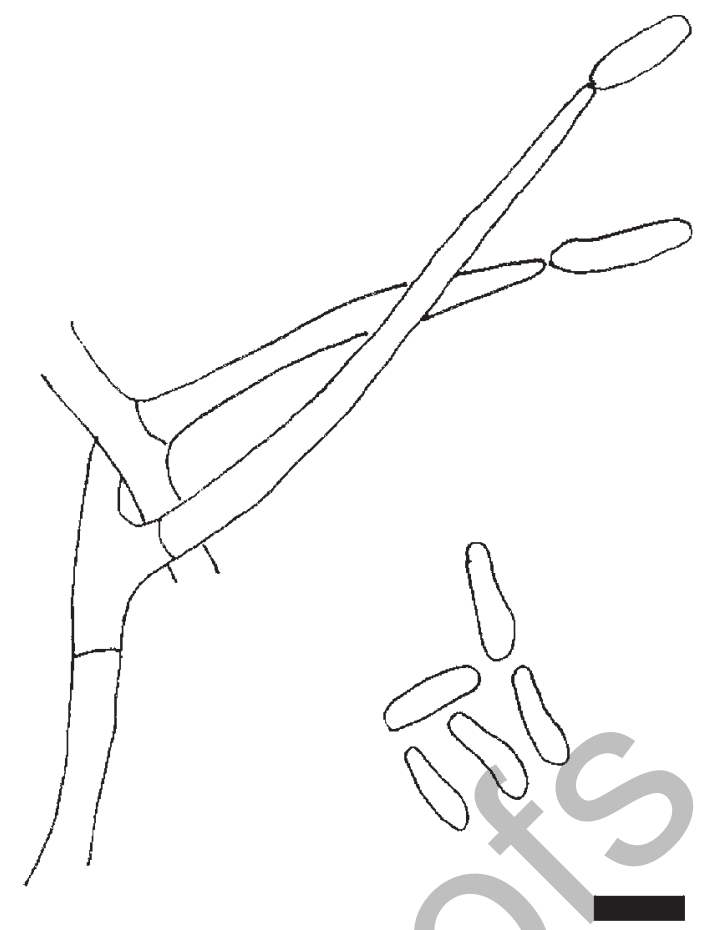

Fig. 3. Hypha, phialides and conidia of Cordyceps locustiphila. Bars $=5 \mu \mathrm{m}$.

ITS region, and at bp $213(\mathrm{~A} / \mathrm{C})$ and 221 (T/A) for the TEF region to those derived from the ascostroma.

SPECIMEN EXAMINED: ARGENTINA. MISIONES, Departamento, Yabotí biosphere reserve: $26^{\circ} 37^{\prime}$ S, $54^{\circ} 10^{\prime} \mathrm{W}, 200$ to 648 m.s.n.m., on Tropidacris collaris (Orthoptera: Acridoidea: Romaleidae), (LPSC WDCM1001- La Plata Spegazzini Collection; and www.museo.fcnym.unlp.edu.ar/micologia colecciones), S. Pelizza, LPS\#49245, deposited in the herbarium of the Spegazzini Institute in November 2015, culture LPSc 1218.

\section{Discussion}

Our detection constitutes the first record of C. locustiphila infecting T. collaris. Until now C. locustiphila was known to occur only in the grasshopper Colpolopha sp., also among the Romaleidae, the most diversified family of endemic neotropical grasshoppers (Cigliano et al. 2014). This record of C. locustiphila is the first for Argentina and the southernmost known one, since the previous records of this entomopathogenic fungus were carried out in different regions of the Amazon jungle in Brazil, Colombia, Ecuador, and Perú (Sanjuan et al. 2014). 
Our specimen appears related with the one described by Sanjuan et al. (2014) parasitizing Colpolopha laetipenis due to the gregarious, claviform, simple, and bright yellow stromata, but differs from it in size. In Sanjuan et al. (2014) the stromata were 12-20 $\mathrm{mm}$ long while in our specimen stromata were 5-10 $\mathrm{mm}$ long. Differences between these two specimens of $C$. locustiphila are also found in perithecia. The perithecia of $C$. locustiphila found in Colpolopha measured 550-600 x 250-320 $\mu \mathrm{m}$, whereas those found on $T$. collaris measured 358-488 × 138-232 $\mu \mathrm{m}$. In summary, we observed that the different structures measured (stromata and perithecia) were slightly smaller in $C$. locustiphila found on $T$. collaris than that found in specimens of the genus Colpolopha., which may be based on the immaturity of our specimen.

Until now, it was speculated that $C$. locustiphila had a beauveria anamorph (Sanjuan et al. 2014), but this speculation could not be corroborated. The molecular analysis on the acremonium-like anamorph obtained in culture strongly confirmed that it belongs to $C$. locustiphila. The recent new combination $B$. locustiphila was made merely to comply with the $1 \mathrm{~F}=1 \mathrm{~N}$ rule without providing new data for this species (Kepler et al. 2017). Our finding of an acremonium-like anamorph indicates that this combination might be premature and that more study is necessary in the Beauveria clade before sound nomenclatural conclusions can be proposed.

Even though further research is necessary in order to properly describe the anamorph we think it is important to communicate the detection of this new isolate. When outbreaks of $T$. collaris occur, control measures still rely exclusively on chemical insecticides and the eventual development of a biological control alternative would be a significant environmental-friendly step forward.

\section{Acknowledgements}

We strongly appreciate the critical revision and the valuable comments of Dr. Roland Kirschner which helped us to improve our manuscript. This study was partially supported by Consejo Nacional de Investigaciones Científicas y Tecnológicas (PIP 0018), Universidad Nacional de La Plata (UNLP, 11/N 773), Comisión de Investigaciones Científicas de la provincia de Buenos Aires (CICPBA) and Fondo para la Investigación Científica y Tecnológica (FONCYT; PICT2015-1146, PICT2012-0199).

\section{References}

ANDRADE, C. 1980: Epizootia natural causada por Cordyceps unilateralis (Hypocreales, Euascomycetes) em adultos de Camponotus sp. (Hymenoptera, Formicidae) na região de Manaus, Amazonas, Brasil. - Acta Amazónica 10: 671-677. http://dx.doi.org/10.1590/1809-43921980103671.

BARDI, C., S.A. PELIZZA \& C.E. LANGE 2009.Un nuevo enemigo natural de la "tucura quebrachera" Tropidacris collaris (Orthoptera: Romaleidae): Gregarina sp. (Apicomplexa: Eugregarinorida: Gregarinidae). - V Congreso Argentino de Parasitología, La Plata, Argentina.

BECNEL, J.J. 2012: Complementary techniques: preparations of entomopathogens and diseased specimens for more detailes study using microscopy. - In: LACEY, L.A. (ed.): Manual of techniques in invertebrate pathology, second edition, pp. 451-470. -Academic Press, an imprint of Elsevier, London. https://doi.org/10.1016/B978-0-12-386899-2.00015-4 
CABRERA, A.L. \& A. WILLINK 1973: Biogeografía de América Latina. Monogr. 13, Ser. Biol. Washington, DC: OEA. http://dx.doi.org/10.24201/edu.v4i02.1541

CIGLIANO, M.M., M.E. POCCO \& C.E. LANGE 2014: Acridoideos (Orthoptera) de importancia agroeconómica en la República Argentina. - In: ROIG JUNENT, S.A., L.C. CLAPS \& J.J. MORRONE (eds.): Biodiversidad de Artrópodos Argentinos. Vol. 3., pp. 1-36. - Editorial INSUE, Universidad Nacional de Tucumán, Argentina.

DI BITETTI, M.S., G. PLACCI, \& L.A. DIETZ 2003: Una Visión de Biodiversidad para la Ecorregión del Bosque Atlántico del Alto Paraná. Washington, D.C., World Wildlife Fund, p. 154.

EVANS, H.C., S. ELLIOT \& D. HUGHES 2011: Hidden diversity behind the zombie-ant fungus Ophiocordyceps unilateralis: Four new species described from carpenter ants in Minas Gerais, Brazil. - PLoS ONE 6: e17024. https://doi.org/10.1371/journal.pone.0017024

EVANS, H.C. \& R.A. SAMSON 1982: Cordyceps species and their anamorphs pathogenic on ants (Formicidae) in tropical forest ecosystems I. The Cephalotes (Myrmicinae) Complex. - Trans. Br. Mycol. Soc. 79: 431-453. https://doi.org/10.1016/S0007-1536(82)80037-5

HAWKSWORTH, D.L. \& A.Y. ROSSMAN 1997: Where are all the undescribed fungi? Phytopathology 87: 888-891. https://doi.org/10.1094/PHYTO.1997.87.9.888

HENNINGS, P. 1904: Fungi amazonici II. a cl. Ernesto Ulecollecti. - Hedwigia 43: 246-249.

KEPLER, R.M., J.J. LUANGSA-ARD, N.L. HYWEL-JONES, C.A. QUANDT, G. SUNG et al. 2017. A phylogenetically-based nomenclature for Cordycipitaceae (Hypocreales). - IMA FUNGUS 8: $335-353$.

KOBAYASI, Y. 1941: The genus Cordyceps and its allies. - Science Reports of the Tokyo Bunrika Daigaku Sec. B 84: 53-260.

KOBAYASI, Y. 1981: Revision of the Genus Cordyceps and Its Allies I. - Bulletin of the National Science Museum Tokyo. Ser. B 7: 1-13.

LACEY, L.A. \& L.F. SOLTER 2012: Initial handling and diagnosis of diseased invertebrates. - In: LACEY, L.A. (ed.): Manual of techniques in invertebrate pathology, pp. 1-14. - Academic Press, an imprint of Elsevier, London. https://doi.org/10.1016/B978-0-12-386899-2.00001-4

LÓPEZ-LASTRA, C.C 1989: Primera cita de Cordyceps sobolifera (Ascomycotina: Pyrenomycetes) patógeno de insectos en la República Argentina. - Boletín de la Sociedad Argentina de Botánica 26: $59-60$.

LUANGSA-ARD, J.J., T. KANOKSRI, S. MONGKOLSAMRIT \& N. HYWEL-JONES 2008: Atlas of Invertebrate-Pathogenic Fungi of Thailand Vol. 2. - National Center for Genetic Engineering and Biotechnology, Thailand.

MAINS, E.B. 1954: Species of Cordyceps on spiders. - Bull. Torrey Bot. Club 81: 492-500. DOI: $10.2307 / 2481945$

MAINS, E.B. 1958: North American entomogenous species of Cordyceps. - Mycologia 50: 169-222. DOI: $10.2307 / 3756193$

MAINS, E.B. 1959: Cordyceps species. - Bull. Torrey Bot. Club 86: 46-58. DOI: 10.2307/2482660

MARCHIONATTO, J. 1945: Un nuevo Cordyceps (Ascomicetas) sobre araña pollito. -Physis Revista de la Sociedad Argentina de Ciencias Naturales 20: 16-18.

MORRONE, J.J. 2014: Biogeographical regionalization of the Neotropical region. - Zootaxa 3782: 1-110. http://dx.doi.org/10.11646/zootaxa.3782.1.1

MUELLER, G.M. \& M. RAJCHENBERG 1991: First report of Cordyceps from South American Nothofagus forests. - The Mycologist 5: 46-47. https://doi.org/10.1016/S0269-915X(09)80345-5 
REHNER, S.A. \& E. BUCKLEY 2005: A Beauveria phylogeny inferred from nuclear ITS and EF1 a sequences: evidence for cryptic diversification and links to Cordyceps teleomorphs. - Mycologia 97: 84-98. http://dx.doi.org/10.1080/15572536.2006.11832842

SAMSON, R.A., H.C. EVANS \& J.P. LATGÉ 1988: Atlas of entomopathogenic fungi. - SpringerVerlag, Berlin, Heidelberg, New York.

SANJUAN, T., L. HENAO \& G. AMAT 2001: Distribución espacial de Cordyceps spp. (Ascomycotina: Clavicipitaceae) y su impacto sobre las hormigas en selvas del piedemonte Amazónico de Colombia. - Revista de Biología Tropical 49: 945-955.

SANJUAN, T., J. TABINA, S. RESTREPO, T. LAESSOE, J.W. SPATAFORA et al. 2014: Entomopathogens of Amazonian stick insects and locust are members of the Beauveria species complex (Cordyceps sensu stricto). - Mycologia 106: 260-275. http://dx.doi.org/10.3852/13-020

SANJUAN, T.I., A.E. FRANCO-MOLANO, R.M. KEPLER, J.W. SPATAFORA, J. TABIMA et al. 2015: Five new species of entomopathogenic fungi from the Amazon and evolution of neotropical Ophiocordyceps. - Fungal Biology 119: 901-916. https://doi.org/10.1016/j.funbio.2015.06.010

SPEGAZZINI, C. 1919: Cordyceps submilitaris Hnng. - Los Hongos de Tucuman. p. 267.

STENGLEIN, S. \& P. BALATTI 2006: Genetic diversity of Phaeoisariopsis griseola in Argentina as revealed by pathogenic and molecular markers. - Physiology and Molecular Plant Pathology 68: 158-167. https://doi.org/10.1016/j.pmpp.2006.10.001

STENSRUD, Ø., N. HYWEL-JONES \& T. SCHUMACHER 2005: Towards a phylogenetic classification of Cordyceps: ITS nrDNA sequence data confirm divergent lineages and paraphyly.Mycol. Res. 109: 41-56. https://doi.org/10.1017/S095375620400139X

SUNG, G.H., J.M. SUNG, N.L. HYWEL-JONES \& J.W. SPATAFORA 2007a: A multigene phylogeny of Clavicipitaceae (Ascomycota, Fungi): identification of localized incongruence using a combinational bootstrap approach. - Mol. Phyl. Evol. 44: 1204-1223. https://doi.org/10.1016/j. ympev.2007.03.011

SUNG, G.H., N. HYWEL-JONES, J. SUNG, J. LUANGSA-ARD, B. SHRESTHA et al. 2007b: Phylogenetic classification of Cordyceps and the clavicipitaceous fungi. - Stud. Mycol. 57: 5-59. https://doi.org/10.3114/sim.2007.57.01

WHITE, T.J., T. BRUNS, S. LEE \& J.W. TAYLOR 1990: Amplification and direct sequencing of fungal ribosomal RNA genes for phylogenetics. - In: INNIS, M.A., D.H. GELFAND, J.J. SNINSKY \& T.J. WHITE (eds.): PCR protocols: A guide to methods and applications, pp. 315-322, San Diego, Academic Press. https://doi.org/10.1016/B978-0-12-372180-8.50042-1

YASEM DE ROMERO, M. 1984: Primera cita de Cordyceps dipterigena Berck. \& Br. (=Hymenostilbe dipterigena Petch) para la República Argentina. CIRPON 2: 65-69.

Manuscript submitted August 12, 2017; accepted December 28, 2017. 